\title{
Microbiological changes throughout the manufacturing and ripening of a Spanish goat's raw milk cheese (Armada variety)
}

\author{
ME Tornadijo ${ }^{1}$, JM Fresno ${ }^{1}$, A Bernardo ${ }^{1}$, \\ R Martín Sarmiento ${ }^{1 *}, \mathrm{~J}$ Carballo ${ }^{2}$ \\ 1 Departamento de Higiene y Tecnologia de los Alimentos, Universidad de León, 24071 León; \\ 2 Area de Tecnología de los Alimentos, Facultad de Ciencias de Orense, \\ Universidad de Vigo, 32004 Orense, Spain
}

(Received 7 March 1995; accepted 5 July 1995)

\begin{abstract}
Summary - The microbial groups of technological interest (aerobic mesophilic flora, presumptive lactococci, presumptive lactobacilli, presumptive leuconostocs, presumptive enterococci, presumptive Micrococcaceae and moulds and yeasts) were enumerated throughout the ripening process in 4 batches of Armada goat's milk cheese (2 ripened in summer and 2 ripened in autumn). High counts of all microbial groups were observed in milk $\left(\log _{10} \mathrm{cfu} / \mathrm{g}\right.$ : aerobic mesophilic flora $6.72-7.55$, presumptive lactococci $6.53-7.40$, presumptive lactobacilli $4.84-5.05$, presumptive leuconostocs $5.47-5.68$, presumptive enterococci 2.94-4.29, presumptive Micrococcaceae 4.47-4.66, moulds and yeasts 4.59-4.66); the highest counts being generally reached in all the microbial groups in 1-week-old cheese. Beyond this, they progressively dropped until the end of ripening. In the first 8 weeks of ripening, no significant differences were observed in the counts related to the season when the cheeses were ripened. Only in 16-week-old cheeses were the counts in ripened cheeses during the summer lower than those determined in autumn ripened cheeses. The lactic acid bacteria were the most abundant flora during manufacturing and ripening of this cheese. Lactococci (Lactococcus lactis subsp lactis and Lactococcus lactis subsp cremoris) dominated in milk ( $50 \%$ of the isolates carried out in $\mathrm{M} 17$ agar), curd ( $70 \%$ of the isolates carried out in M17 agar) and 1-week-old cheese $(70 \%$ of the isolates carried out in M17 agar) and lactobacilli (mainly Lactobacillus casei subsp casei and Lactobacillus plantarum) were the most abundant group during the last stages of ripening $(92.5,95$ and $77.5 \%$ of the isolates carried out in Rogosa agar in 4-, 8- and 16-week-old cheese, respectively). M17 agar showed a moderate selectivity for the isolation of lactococci $(\mathbf{4 5 . 7 1 \%}$ of the isolates carried out in M17 agar were classified as lactococci). The selectivity of MSE agar for the isolation of leuconostoc was very low (only $16.42 \%$ of the isolates carried out in MSE agar were classified as leuconostocs). On the other hand, Rogosa agar and KAA agar showed a very high selectivity for the isolation of lactobacilli and enterococci, respectively
\end{abstract}

* Correspondence and reprints. 
( $86.42 \%$ of the isolates carried out in Rogosa agar were classified as lactobacilli and $91.85 \%$ of the isolates carried out in KAA agar were classified as enterococci). Values of some physicochemical parameters ( $\mathrm{pH}, \mathrm{a}_{\mathrm{w}}$ and moisture and $\mathrm{NaCl}$ contents) as well as the correlation coefficients between the values of these parameters and the microbial group counts throughout ripening were also determined.

\section{Armada cheese / goat cheese / microbiological change / lactic acid bacteria}

Résumé - Modifications de la flore bactérienne pendant la fabrication et l'affinage du fromage de chèvre Armada, une variété espagnole fabriquée à partir de lait cru. La présente étude a porté sur la numération de différents groupes microbiens d'intérêt technologique (germes aérobies mésophiles totaux, lactocoques, lactobacilles, leuconostocs, entérocoques et micrococcaceae présumés et moisissures et levures) lors de la fabrication et l'affinage de 4 fabrications de fromages de chèvre de la variété Armada (2 affinés en été et 2 autres affinés en automne). L'analyse du lait a révélé un nombre élevé de microorganismes appartenant aux différents groupes étudiés $\left(\log _{10}\right.$ ufc/g: Germes aérobies mésophiles totaux $6,72-7,55$; lactocoques présumés $6,53-7,40$; lactobacilles présumés $4,84-5,05$ ; leuconostocs présumés $5,47-5,68$; entérocoques présumés $2,94-4,29$; micrococcaceae présumés 4,47-4,66; moisissures et levures 4,59-4,66). Pour la majorité des groupes microbiens étudiés, les niveaux de population les plus élevés ont été trouvés dans le fromage âgé d'une semaine. À partir de ce moment, la charge microbienne a progressivement diminué jusqu'à la fin de l'affinage. Nous avons pu constater que les fromages affinés en été n'ont présenté des dénombrements significativement inférieurs à ceux affinés en automne que pendant la seizième semaine d'affinage. Les bactéries lactiques ont constitué la flore la plus abondante durant les phases de fabrication et d'affinage du fromage ; 1120 souches ont été isolées et identifiées à partir du lait, du caillè et du fromage pendant l'affinage. Les lactocoques (Lactococcus lactis subsp lactis et Lactococcus lactis subsp cremoris) ont formé le groupe majoritaire du lait ( $50 \%$ des souches isolées dans le milieu M17), du caillé ( $70 \%$ des souches isolées dans le milieu M17) et du fromage d'une semaine ( $70 \%$ des souches isolées dans le milieu M17), tandis que les lactobacilles (surtout Lactobacillus casei subsp casei et Lactobacillus plantarum) furent les plus abondants durant la dernière période de la maturation $(92,5 \%, 95 \%$ et $77,5 \%$ des souches isolées dans le milieu Rogosa respectivement du fromage de 4,8 et 16 sem). La sélectivité du milieu M17 s'est révélée modérée pour dénombrer les lactocoques $(45,71 \%$ des souches isolées dans ce milieu ont été classées comme lactocoques) ; celle du milieu MSE (pour les leuconostocs) est encore plus faible (seulement $16,42 \%$ des souches isolées dans ce milieu ont été classées comme leuconostocs). En revanche, les milieux Rogosa et KAA sont apparus très sélectifs pour isoler respectivement les lactobacilles et les entérocoques $(86,42 \%$ des souches isolées dans le milieu Rogosa ont été classées comme lactobacilles et $91,85 \%$ des souches isolées dans le milieu KAA ont été classées comme entérocoques). Nous avons aussi déterminé les valeurs de certains paramètres physicochimiques ( $\mathrm{pH}$, aw, teneurs en sel et humidité), ainsi que les coefficients de corrélation entre les valeurs de ces parametres et le dénombrement des différents groupes microbiens tout au long de l'affinage. Le pH a chuté de 6,6 dans le lait à 5,1 dans le caillé, a atteint sa valeur minimale dans les fromages âgés d'une à $4 \mathrm{sem}(4,3$ à 4,6$)$ puis s'est stabilisé autour de 5,0 en fin d'affinage. Les valeurs moyennes de la teneur en humidité et de l'activité de l'eau atteintes en fin d'affinage se sont situées à respectivement $21,1 \%$ et 0,902 . Les teneurs en $\mathrm{NaCl}$ ont montre une variation importante d'un fromage à l'autre, du fait du procédé de salage mis en oeuvre. La diminution de l'ensemble des groupes microbiens étudiés semble être essentiellement due à la chute des valeurs d'activité, de l'eau ainsi qu'à l'abaissement du pH. Le salage ne semble pas en revanche avoir influencé les niveaux de population microbienne.

fromage Armada / fromage de chèvre / évolution de la flore bactérienne / bactérie lactique 


\section{INTRODUCTION}

Spain produces a large quantity of goat's milk (about 400 million litres/year) and approximately $40 \%$ is used in cheesemaking. Although 28 varieties of goat cheeses (MAPA, 1990) are listed in this country, they are not very well distributed on the market, and only 1 variety (Majorero cheese) is produced on an industrial scale. This situation is mainly due to a lack of information on production methods and biochemical and microbiological characteristics, which prevents manufacture under controlled conditions.

Among the Spanish goat's milk cheeses, only Valdeteja (Gutiérrez et al, 1988), Majorero (Gómez et al, 1989; Fontecha et al, 1990), Ibores (Mas Mayoral et al, 1991; Mas and González-Crespo, 1992), Cendrat del Montsec (Mor-Mur et al, 1992) and Gredos (Medina et al, 1992) have been extensively studied for their microbiological characteristics. There is a lack of studies on the bacterial flora of other varieties.

The Armada cheese, a hard variety made in the north of Spain, is included in the group not yet studied. This cheese is made from raw goat's milk, without addition of starter cultures, using artisanal procedures so its quality is very variable, which makes difficult its diffusion in the national and international markets. The results published on this cheese refer only to the study of Enterobacteriaceae throughout the manufacturing and ripening process (Tornadijo et al, 1993).

The aim of this work was to study the groups of microorganisms which are the most relevant in ripening, throughout the ripening process of Armada cheese. It constitutes a preliminary study in order to elaborate an adequate starter culture which would permit the manufacturing on an industrial scale of a uniform product, and preserve the quality characteristics of the artisanal product as much as possible.

\section{MATERIALS AND METHODS}

\section{Manufacturing of cheeses and sampling}

Four batches of Armada cheese (2 ripened in summer and 2 ripened in autumn) were made by experimented cheesemakers following the traditional methods. Raw whole goat's milk was coagulated at $30^{\circ} \mathrm{C}$ by adding about $15 \mathrm{ml}$ of commercial calf rennet (strength $1 / 10000$ ) (Productos Nievi, Bilbao, Spain) for each 100 l of milk. One hour later, the curd, compact at this stage, was cut and transferred to cheesecloths. These were formed in bundles and hung for $48 \mathrm{~h}$ to drain the whey. The bundles were then opened and the curd given a rigorous kneading ("sobado"). It was then transferred to clean cheesecloths and hung for another $3 \mathrm{~d}$ after which it was kneaded and hand-moulded to give the characteristic square form. The cheeses were then wrapped again in cheesecloths and hung from the ceilings where the ripening process took place at a temperature of $10-15^{\circ} \mathrm{C}$ and a relative humidity of $70-85 \%$ depending on the time of year. Salting was carried out by adding solid salt during the kneading operations.

Milk, curd ( $6 \mathrm{~h}$ after placing in the cheesecloths), and 1-, 2-, 4-, 8- and 16-week-old cheese (each sample was constituted of 1 whole cheese) samples were taken from each batch. Samples were transported to the laboratory under refrigeration (below $5^{\circ} \mathrm{C}$ ) and analyzed on arrival.

\section{Microbiological analysis}

Fifty $\mathrm{g}$ of each sample (after discarding the rind of the cheeses) were homogenized with $200 \mathrm{ml}$ of a sterile solution of $2 \%$ sodium citrate at $40-45^{\circ} \mathrm{C}$ for $1 \mathrm{~min}$ in a Stomacher 400 Lab Blender (Seward Medical, London, England), thus making a $1 / 5$ dilution. Consecutive decimal dilutions were prepared by mixing $10 \mathrm{ml}$ with $90 \mathrm{ml}$ of $0.1 \%$ sterile peptone water. Aerobic mesophilic bacteria were enumerated in standard plate count agar (Oxoid, Ltd, Basingstoke, England) after incubation at $30^{\circ} \mathrm{C}$ for $48 \mathrm{~h}$ (ICMSF, 1978), presumptive lactococci in M17 agar (Biokar Diagnostics, Beauvais, France) (Terzaghi and Sandine, 1975) after incubation at $30^{\circ} \mathrm{C}$ for $18 \mathrm{~h}$, presumptive lactobacilli in Rogosa agar (Oxoid) (Rogosa et 
al, 1951) after incubation at $30^{\circ} \mathrm{C}$ for $5 \mathrm{~d}$ and presumptive leuconostocs in MSE agar (Biokar) (Mayeux et al, 1962) after incubation at $22^{\circ} \mathrm{C}$ for 4 d. Presumptive enterococci were determined on KAA agar (Oxoid) (Mossel et al, 1978) incubated for $24 \mathrm{~h}$ at $37^{\circ} \mathrm{C}$, presumptive Micrococcaceae on Mannitol salt agar (Oxoid) (Chapman, 1945 ) incubated for $48 \mathrm{~h}$ at $30^{\circ} \mathrm{C}$, and moulds and yeasts on OGYE agar (Oxoid) (Mossel et al, 1970) incubated for $5 \mathrm{~d}$ at $22^{\circ} \mathrm{C}$. In standard plate count agar, Rogosa agar, KAA agar and OGYE agar, $1 \mathrm{ml}$ volumes of each dilution were inoculated in duplicate and mixed before solidification. Plates of Rogosa agar were covered with a layer of the same medium before incubation. In MSE agar, M17 agar and Mannitol salt agar, $0.1 \mathrm{ml}$ volumes of each dilution were surface plated in duplicate.

After the end of the incubation period, from the M17 agar, MSE agar, Rogosa agar and KAA agar plates, 10 colonies were randomly taken from each sampling point and from each medium with the aid of a Harrison disc (Harrigan and McCance, 1976a). The isolates from M17 agar, MSE agar and Rogosa agar were purified by 4 alternate subcultures in MRS agar and MRS broth (Oxoid). Isolates from KAA agar were purified in nutrient agar - nutrient broth (Oxoid). The isolated strains were, afterwards, maintained in Robertson's cooked meat medium (Harrigan and McCance, $1976 \mathrm{~b}$ ) below $4^{\circ} \mathrm{C}$.

Homofermentative, Gram-positive, catalasenegative cocci, which were capable of growing at 10 and $40^{\circ} \mathrm{C}$ but not at $45^{\circ} \mathrm{C}$ or at $6.5 \%$ salt or at $\mathrm{pH} 9.6$, were considered as lactococci and were classified according to the methods and criteria of Sharpe (1979) and Mundt (1986b). The following tests were carried out on each isolate: hydrolysis of arginine; growth in $4.5 \% \mathrm{NaCl}$ broth; acetoin production; utilization of $\mathrm{L}$-arabinose, $\mathrm{D}$ xylose, sucrose, trehalose, mannitol, salicin, raffinose, inulin, glycerol, sorbitol, rhamnose, ribose and maltose.

The Gram-positive, catalase-negative cocci, grouped in pairs or short chains, homofermentative, which grew at $10,37,40$ and generally at $45^{\circ} \mathrm{C}$, generally survived after heating at $60^{\circ} \mathrm{C}$ after $30 \mathrm{~min}$, grew in a $6.5 \%$ salt, at a $\mathrm{pH} 9.6$ and in $40 \%$ bile, and formed red or pink colonies generally with a yellowish halo in KF Streptococcus agar (Difco Laboratories, Detroit, MI, USA), were considered as enterococci and were classified according to the methods and criteria described by Sharpe (1979), Collins et al (1984), Colman and Ball (1984), Mundt (1986b) and Devriese et al (1987). The following tests were carried out on each isolate: growth at $50^{\circ} \mathrm{C}$; hydrolysis of arginine; reduction of $0.1 \%$ methylene blue milk; growth in $0.04 \%$ potassium tellurite broth; utilization of L-arabinose, arbutin, melezitose, melibiose, sorbitol, sorbose, rhamnose, raffinose, starch and sucrose.

The Gram-positive, catalase-negative, heterofermentative cocci which did not hydrolyze arginine (leuconostoc) were characterized according to the methods and criteria of Garvie (1984, 1986). The following tests were carried out on each isolate: growth at $37^{\circ} \mathrm{C}$ and in 4 and $6.5 \%$ $\mathrm{NaCl}$ broth; dextran production; utilization of $\mathrm{L}$ arabinose, cellobiose, fructose, glucose, lactose, maltose, melibiose, sucrose, salicin and trehalose.

Gram-positive, catalase-negative rods (lactobacilli) were characterized according to the methods and criteria of Sharpe (1979) and Kandler and Weiss (1986). The following tests were carried out on each isolate: growth at 15 and $45^{\circ} \mathrm{C}$; gas production from glucose; hydrolysis of arginine; utilization of L-arabinose, cellobiose, lactose, melezitose, melibiose, raffinose, salicin, trehalose, D-xylose, mannose, sucrose, inulin, rhamnose, sorbitol and sorbose.

\section{Chemical analysis}

Moisture and $\mathrm{NaCl}$ contents in curd and cheese were determined according to the IDF standards $4 \mathrm{~A}$ (1982) and 17A (1972), respectively. The $\mathrm{pH}$ values in curd and cheese were measured according to the 14022 AOAC (1975) method. Moisture content in milk was determined according to the IDF standard 21B (1987). NaCl content in milk was determined according to the French standard (Norme Francaise Homologuée) $\mathrm{V} 04-212$ (1969). The $\mathrm{pH}$ of milk was measured directly with a $\mathrm{pH}$ meter PHM 82 Standard (Radiometer, Copenhagen, Denmark). Water activity $\left(\mathrm{a}_{\mathrm{w}}\right)$ was measured with a Decagon $\mathrm{CX}$ 1 Water Activity System apparatus (Decagon Devices, Pullman, WA, USA).

\section{Statistical analysis}

Analysis of variance was carried out to investigate the differences in the counts of the different 
microbial groups between the batches ripened in summer and in autumn.

Correlations between counts of the microbial groups and physicochemical parameters were determined with the aid of the computer programme SPSS/PC+ version 3.1 (SPSS Inc, Chicago, IL, USA).

\section{RESULTS AND DISCUSSION}

\section{Changes in the microbial groups throughout ripening}

Tables I and II show the evolution of the counts of the investigated microbial groups throughout the maturation of the batches ripened in summer and autumn, respectively. The milk used in the manufacture of the cheeses had high microbial counts $\left(\log _{10}\right.$ counts of aerobic mesophilic flora $6.72-7.55 / \mathrm{g})$. Although similar counts have been observed in goat's milk used in the manufacture of other varieties of cheese (Fatichenti et al, 1979; Gutiérrez et al, 1988; Fontecha et al, 1990; Mas Mayoral et al, 1991), these values were very much higher than those reported by other authors (Espie and Mullan, 1987; Tirard-Collet et al, 1991; Medina et al, 1992) and they were the consequence of the hand milking in unhygienic conditions and of the absence of refrigeration after milking. The counts of the other microbial groups in milk were also high but within the range of those observed in milk used in the manufacture of other goat cheeses (Fatichenti et al, 1979; Gutiérrez et al, 1988; Fontecha et al, 1990; Mas Mayoral et al, 1991).

The counts reached in curd by the investigated microbial groups were, on average, $1 \log _{10}$ unit higher than those observed in milk. The increase of the microbial counts in curd is usual in cheese manufacture and is partly due to the microbial multiplication and partly to the physical retention of the microorganisms in the coagulum during the whey drainage. The increase observed in Armada curd was similar to that described by Medina et al (1992) in Gredos cheese and by Gutiérrez et al (1988) in Valdeteja cheese. However, Poullet et al (1991) in Casar de Cáceres ewe cheese observed increases notably higher ( $3 \log _{10}$ units). Gómez et al (1989) in Majorero cheese observed even higher increases in total viable counts ( $3-5 \log _{10}$ units); however, it must be taken into account that in this instance pasteurized milk was used to which a starter culture was added before coagulation. The low increases in the counts in Armada cheese curd can be explained by the short period of time between milk and curd sample taking (approximately $7 \mathrm{~h}$ ), in which the microbial multiplication was minimal. This possibility is supported by other authors (Tatini et al, 1971) who conclude that the physical retention of the bacteria in the curd is responsible for the increase in $1 \log _{10}$ unit counts, the remaining increase being due to microbial multiplication.

The highest counts of all the microbial groups were reached, generally, in 1-weekold cheese. The increase in count during the first week of ripening was accompanied by a sharp drop in $\mathrm{pH}$ values (about 2 units) (fig 1) which is a consequence of the production of acid by the microorganisms. This sharp drop in $\mathrm{pH}$ is logical if one takes into account that the lactococci (main producers of lactic acid) were the dominant microbial group in milk, curd and 1-week-old cheese.

After the first week of ripening, the counts of all the microbial groups fell slowly and irregularly, reaching, after 16 weeks of ripening, in the batches ripened in autumn, counts on average $1 \log _{10}$ unit lower than those shown in 1-week-old cheese (table II). The decrease undergone by the lactococci in these 2 batches ( $2.45 \log _{10}$ units) was noticeable. In the batches ripened in summer (table I), the decrease in the counts throughout ripening was higher (the counts 
Table I. Changes in $\log _{10} \mathrm{cfu} / \mathrm{g}$ of main microbial groups of Armada cheese ripened in summer.

Évolution des comptages (log ufc/g) des principaux groupes microbiens du fromage Armada affiné en été.

\begin{tabular}{|c|c|c|c|c|c|c|c|}
\hline Microbial group & Milk & Curd & 1 & 2 & 4 & 8 & 16 \\
\hline Aerobic mesophilic flora & $6.72 \pm 0.15$ & $8.29 \pm 0.14$ & $9.37 \pm 0.55$ & $8.65 \pm 0.35$ & $8.69 \pm 0.55$ & $7.42 \pm 0.17$ & $4.39 \pm 0.03$ \\
\hline Presumptive lactococci & $6.53 \pm 0.07$ & $7.89 \pm 0.40$ & $9.48 \pm 0.56$ & $8.41 \pm 0.26$ & $7.14 \pm 0.40$ & $6.80 \pm 0.04$ & $4.17 \pm 0.40$ \\
\hline Presumptive leuconostocs & $5.47 \pm 0.21$ & $6.95 \pm 0.66$ & $8.60 \pm 0.71$ & $8.21 \pm 0.01$ & $8.23 \pm 0.17$ & $7.08 \pm 0.11$ & $3.38 \pm 0.02$ \\
\hline Presumptive enterococci & $4.29 \pm 0.44$ & $5.42 \pm 0.31$ & $6.80 \pm 0.51$ & $6.89 \pm 0.55$ & $6.26 \pm 0.63$ & $3.08 \pm 0.50$ & $0.80 \pm 1.13$ \\
\hline Presumptive Micrococcaceae & $4.47 \pm 0.17$ & $5.21 \pm 0.52$ & $4.74 \pm 0.19$ & $3.89 \pm 0.30$ & $4.03 \pm 1.17$ & $4.00 \pm 2.83$ & $2.58 \pm 0.05$ \\
\hline
\end{tabular}


Table II. Changes in $\log _{10} \mathrm{cfu} / \mathrm{g}$ of main microbial groups of Armada cheese ripened in autumn.

Évolution des comptages (log ufc/g) des principaux groupes microbiens du fromage Armada affiné en automne.

\begin{tabular}{|c|c|c|c|c|c|c|c|}
\hline \multirow[t]{2}{*}{ Microbial group } & \multirow[t]{2}{*}{ Milk } & \multirow[t]{2}{*}{ Curd } & \multicolumn{5}{|c|}{ Ripening time (weeks) } \\
\hline & & & 1 & 2 & 4 & 8 & 16 \\
\hline Aerobic mesophilic flora & $7.55 \pm 0.44$ & $8.46 \pm 0.07$ & $9.21 \pm 0.97$ & $8.84 \pm 0.15$ & $8.37 \pm 0.25$ & $8.75 \pm 0.44$ & $8.14 \pm 0.10$ \\
\hline Presumptive lactococci & $7.40 \pm 0.76$ & $8.47 \pm 0.26$ & $8.83 \pm 0.53$ & $8.55 \pm 0.12$ & $7.50 \pm 0.10$ & $7.05 \pm 0.37$ & $6.38 \pm 0.71$ \\
\hline Presumptive lactobacilli & $5.05 \pm 0.00$ & $6.11 \pm 0.76$ & $8.42 \pm 0.56$ & $8.50 \pm 0.01$ & $8.25 \pm 0.50$ & $8.11 \pm 0.57$ & $8.09 \pm 0.34$ \\
\hline Presumptive leuconostocs & $5.68 \pm 0.40$ & $7.39 \pm 0.02$ & $8.49 \pm 0.03$ & $8.53 \pm 0.04$ & $8.06 \pm 0.23$ & $8.05 \pm 0.53$ & $7.58 \pm 0.12$ \\
\hline Presumptive enterococci & $2.94 \pm 0.32$ & $4.96 \pm 0.38$ & $5.85 \pm 0.61$ & $5.47 \pm 0.00$ & $5.71 \pm 0.20$ & $5.34 \pm 0.02$ & $3.94 \pm 1.70$ \\
\hline Presumptive Micrococcaceae & $4.66 \pm 0.04$ & $5.27 \pm 0.23$ & $5.37 \pm 0.42$ & $5.06 \pm 0.13$ & $5.39 \pm 0.67$ & $3.85 \pm 0.65$ & $4.20 \pm 0.56$ \\
\hline Moulds and yeasts & $4.66 \pm 0.56$ & $5.54 \pm 0.16$ & $6.60 \pm 0.00$ & $6.60 \pm 0.19$ & $6.63 \pm 0.17$ & $5.60 \pm 0.20$ & $5.58 \pm 0.30$ \\
\hline
\end{tabular}


in 16-week-old cheese were in the different microbial groups on average of $4.5 \log _{10}$ units lower than those recorded in 1-weekold cheese), the drop in the enterococci
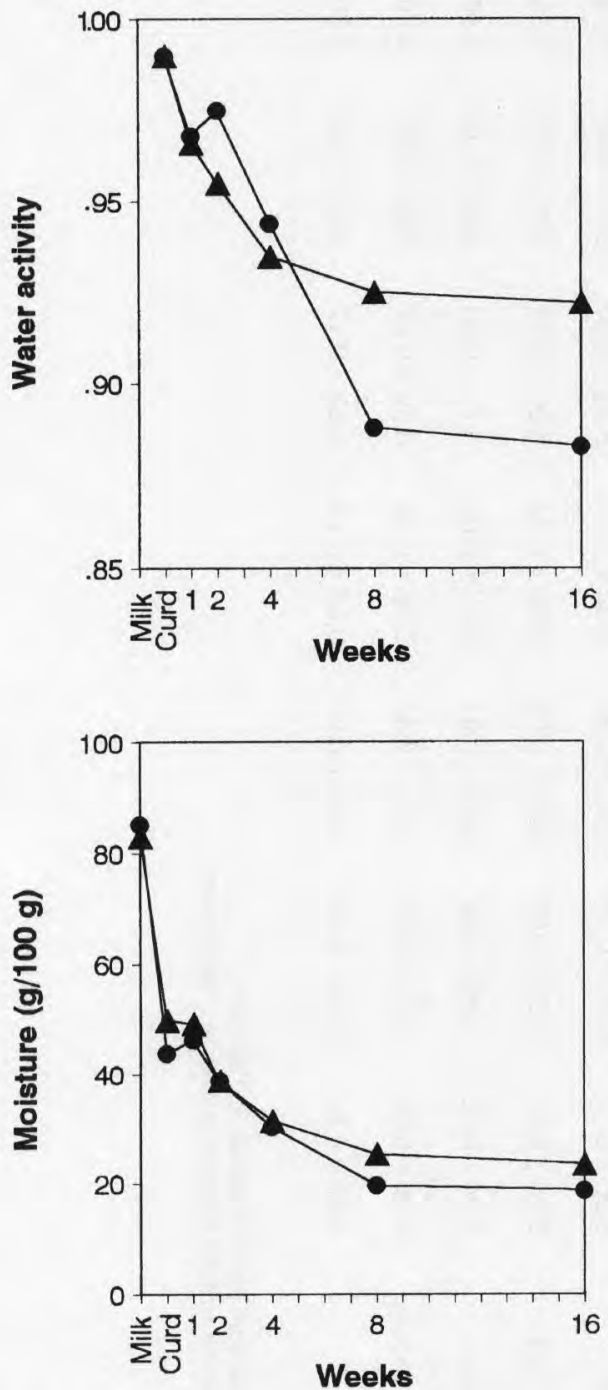

being particularly marked (6 $\log _{10}$ units). The greatest drop in these batches occurred during the last 8 weeks of ripening (on average $2.80 \log _{10}$ units in the different groups).
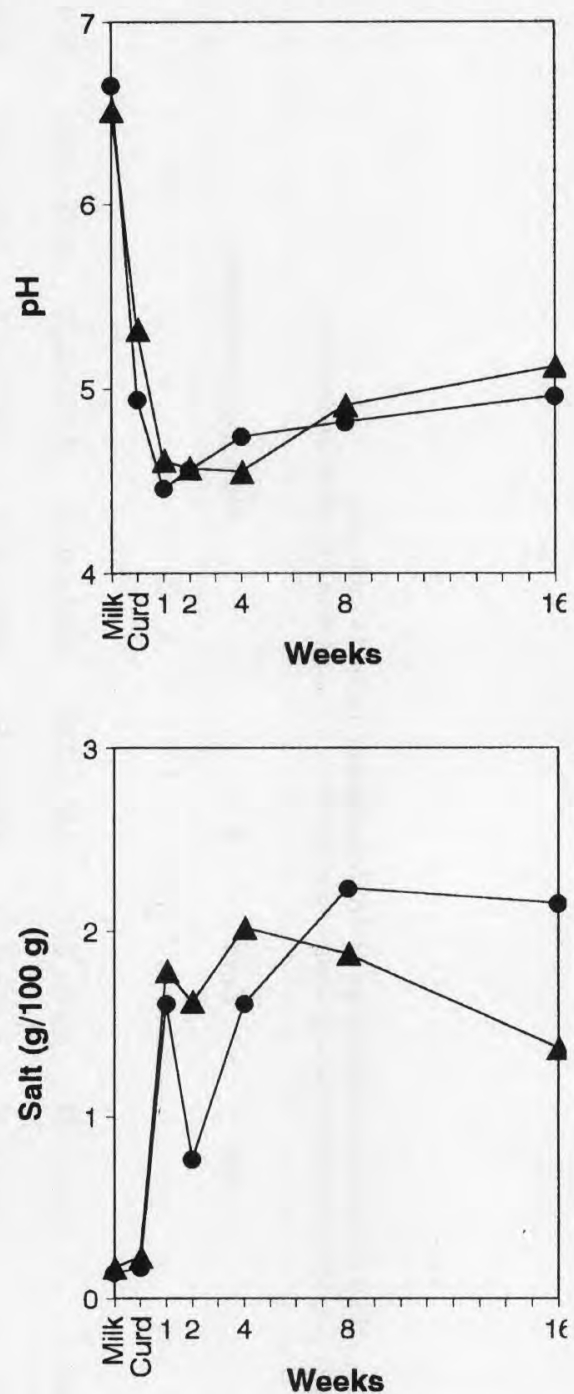

Fig 1. Changes in $\mathrm{a}_{\mathrm{w}}$ and $\mathrm{pH}$ values and in moisture and $\mathrm{NaCl}$ contents throughout the manufacturing and ripening of Armada cheese. Plots show the average of the values measured in the batches ripened in summer ( $)$ and in autumn ( $\mathbf{\Delta})$.

Modifications des valeurs de $\mathrm{a}_{w}, \mathrm{pH}$, humidité et $\mathrm{NaCl}$ durant la fabrication et l'affinage du fromage Armada. Les graphiques montrent les valeurs moyennes des fromages affinés en été (๑) et en automne (4). 
Judging from the correlation coefficients between the different microbial group counts and the physicochemical parameters (table III), the drop in the microbial groups during ripening may have been due to the decrease in water activity. This decrease in water activity was more evident in the batches ripened in summer (fig 1) due to the higher temperatures and lower relative humidity existing in the curing rooms in this season which lead to a greater loss in humidity because of the interchange with its environment. This large fall in $\mathrm{a}_{\mathrm{w}}$ in batches ripened in summer was accompanied by a large decrease in the microbial counts in these batches.

From the correlation coefficients between $a_{w}$ values and microbial counts, presumptive lactococci $(r=0.79)$ and presumptive enterococci ( $r=0.72$ ) seem to be the microbial groups the most affected by the drop in water activity. $\mathrm{pH}$ values in the range 4.3 to 4.8 during most of the ripening period could also influence the fall in microbial counts.

Salting, carried out during the kneading operations, did not seem to have much effect on the counts. Furthermore, the flora which better tolerates salt (Micrococcaceae) was the microbial group which increased least between the curd counts and 1-weekold cheese counts, even decreasing $(0.47$ $\log _{10}$ units) during this period in the batches ripened in summer. The weak growth of Micrococcaceae is probably related to the low $\mathrm{pH}$ values observed in this cheese. It must also be taken into account that this behaviour of Micrococcaceae may be explained by the fact that micrococci are aerobic bacteria which do not grow well at the low redox potential reached inside the cheeses.

It is important to point out that the salt content of the different cheeses is fairly irregular due to the salting technique used. The cheeses were individually salted adding solid salt during the first kneading operation. It is possible that the exact same quan- tity of salt was not added to all the cheeses and it is also probable that the loss in salt content together with the whey, which still drop out from the curd while in cheesecloth before giving them their final shape, were also distinct in the different cheeses.

Overall, considering the 4 batches, the lactobacilli were the dominant microbial group in the last stages of ripening, which was corroborated by the identification of the isolates carried out in the different culture media and observed previously by other authors in different types of cheese (Núñez, 1978; De Giori et al, 1983; Fernández del Pozo et al, 1988; Mas Mayoral et al, 1991; Medina et al, 1992; Tzanetakis and Litopoulou-Tzanetaki, 1992). This circumstance could be due to the great facility the lactobacilli have to grow at low $\mathrm{pH}$ values (Núñez, 1976; McDonald et al, 1990), corroborated by the high negative correlation established between the $\log _{10}$ counts of the presumptive lactobacilli and the $\mathrm{pH}$ values (table III). The high resistance of the lactobacilli to the salt (Sharpe, 1979) may also be the cause of their predominance in the last few stages of ripening.

It may be concluded that the lactic acid bacteria were the predominant flora during manufacturing and ripening of Armada cheese. Micrococcaceae showed initial low counts but they maintained their levels relatively constant during the ripening period (4-5 $\left.\log _{10} \mathrm{cfu} / \mathrm{g}\right)$. Similar steadiness was observed in the yeast and mould counts (about 5-6 $\log _{10} \mathrm{cfu} / \mathrm{g}$ ). The activity of yeasts which metabolize lactic acid was possibly, as well as the liberation of alkaline compounds during breakdown of the proteins, responsible for the increase in $\mathrm{pH}$ after the first week of ripening (fig 1 ).

In the first 8 weeks of ripening no significant differences were observed in the counts of different microbial groups associated to the ripening season. Only in 16week-old cheese (last sampling point) were the counts in the cheeses ripened in sum- 
Table III. Correlation coefficients between the $\log _{10} \mathrm{cfu} / \mathrm{g}$ of main microbial groups and some physicochemical parameters throughout the manufacturing and ripening of Armada cheese (4 batches).

Coefficients de corrélation entre les numérations des différents groupes microbiens et les valeurs de certains paramètres physicochimiques durant la fabrication et l'affinage du fromage Armada (4 fabrications).

\begin{tabular}{|c|c|c|c|c|c|c|c|c|c|c|c|}
\hline & $\begin{array}{l}\text { Aerobic meso- } \\
\text { philic flora }\end{array}$ & Lactococci & Lactobacilli & $\begin{array}{r}\text { Presur } \\
\text { Leuconostocs }\end{array}$ & $\begin{array}{l}\text { Imptive } \\
\text { s Enterococci }\end{array}$ & Micrococcaceae & $\begin{array}{l}\text { Moulds \& } \\
\text { yeasts }\end{array}$ & Salt & $\begin{array}{l}\text { Water } \\
\text { activity }\end{array}$ & Moisture & $p H$ \\
\hline \multicolumn{10}{|l|}{ Aerobic } & & \\
\hline \multicolumn{12}{|l|}{ Presumptive } \\
\hline Lactococci & $0.86^{\star \star \star}$ & 1 & & & & & & & & & \\
\hline Lactobacilli & $0.78^{\star \star \star}$ & $0.55^{\star \star}$ & 1 & & & & & & & & \\
\hline Leuconostocs & $0.93^{\star \star \star}$ & $0.77^{\star \star \star}$ & $0.90^{\star \star \star}$ & 1 & & & & & & & \\
\hline Enterococci & $0.80^{* * *}$ & $0.79^{* * *}$ & $0.68^{\star \star \star}$ & $0.83^{* * *}$ & 1 & & & & & & \\
\hline Microccocaceae & $0.42^{\star}$ & $0.57^{\star \star}$ & $0.18^{\mathrm{NS}}$ & $0.42^{*}$ & $0.39^{\star}$ & 1 & & & & & \\
\hline Moulds and yeasts & $0.80^{\star \star \star}$ & $0.72^{\star \star \star}$ & $0.83^{\star \star \star}$ & $0.89^{\star \star \star}$ & $0.78^{\star \star \star}$ & $0.51^{\star *}$ & 1 & & & & \\
\hline $\mathrm{NaCl}$ & $-0.05^{\mathrm{NS}}$ & $-0.21^{\mathrm{NS}}$ & $0.42^{\star}$ & $0.13^{N S}$ & $-0.03^{\mathrm{NS}}$ & $-0.17^{N S}$ & $0.27^{\mathrm{NS}}$ & 1 & & & \\
\hline$a_{w}$ & $0.62^{\star \star \star}$ & $0.79^{\star \star \star}$ & $0.21^{\mathrm{NS}}$ & $0.55^{\star *}$ & $0.72^{\star \star *}$ & $0.45^{\star}$ & $0.44^{*}$ & $-0.74^{\star \star *}$ & 1 & & \\
\hline Moisture & $-0.00^{N S}$ & $0.26^{\mathrm{NS}}$ & $-0.44^{\star}$ & $-0.19^{N S}$ & $0.04^{N S}$ & $0.31^{N S}$ & $-0.12^{\mathrm{NS}}$ & $-0.70^{\star \star \star}$ & $0.91^{\star \star \star}$ & 1 & \\
\hline $\mathrm{pH}$ & $-0.40^{\star}$ & $-0.27^{\mathrm{NS}}$ & $-0.66^{\star \star \star *}$ & $-0.55^{\star \star}$ & $-0.44^{\star}$ & $0.06^{N S}$ & $-0.50^{* *}$ & $-0.59^{* * *}$ & $-0.07^{N S}$ & $0.75^{\star \star \star}$ & 1 \\
\hline
\end{tabular}

${ }^{\star \star \star} P<0.001 ;{ }^{* \star} P<0.01 ;{ }^{*} P<0.05 ;$ NS $P>0.05$. 
mer lower than those found in the cheeses ripened in autumn. These differences were particularly outstanding in aerobic mesophilic flora $(P<0.001)$, presumptive leuconostocs (counts in MSE agar) $(P<0.001)$ and presumptive lactobacilli (counts in Rogosa agar) $(P<0.05)$.

\section{Species isolated throughout ripening}

Table IV shows the species isolated in M17 agar during the ripening of Armada cheese. M17 agar showed a moderate selectivity for the isolation of lactococci in this cheese (only $45.71 \%$ of isolates obtained in this medium were classified as lactococci). The main lactococci species was Lactococcus lactis subsp lactis. This species constituted $47.5 \%$ of the isolates in milk, its proportion increased in curd $(62.5 \%$ of isolates) and even more in 1 -week-old cheese $170 \%$ of isolates). Its proportion dropped from this sampling point reaching very low proportions in 8-week-old cheese $(12.5 \%$ of isolates) and 16 -week-old cheese $(17.5 \%$ of isolates). The decrease in the number of lactococci took place probably because of the inhibitory effect of low $\mathrm{pH}$ and high $\mathrm{NaCl}$ in moisture concentrations that in 8- and 16-week-old cheese reached values of $9 \%$ on average. This decrease has previously been observed by other authors in different varieties of cheeses (Litopoulou-Tzanetaki and Tzanetakis, 1992; Mas and GonzálezCrespo, 1992; Tzanetakis and LitopoulouTzanetaki, 1992).

Lactobacilli species, which were not isolated from M17 agar in noticeable percentages in the first stages of ripening, constituted the main species in 8-week-old cheese (57.5\% of isolates) and 16-week-old cheese (32.5\% of isolates). The isolation of enterococci after the fourth week of ripening was also noticeable, with Enterococcus faecalis being the main enterococcus isolated species in this medium ( $20 \%$ of isolates in 4 - week-old cheese, $10 \%$ of isolates in 8-weekold cheese and $17.5 \%$ of isolates at the last sampling point).

The number of isolates lost in this culture medium was very high, especially at the first 3 sampling points. It is worth noting that practically all the losses were produced during the purification phase of the strains (alternate cultures in MRS agar MRS broth), which makes us suspect that the isolates lost were probably non-lactic acid bacteria.

Table V shows the species isolated from MSE agar during the ripening of this cheese. Despite its high contents in sucrose $(100 \mathrm{~g} / \mathrm{l})$ and the presence of sodium azide $(0.075$ $g / l)$, MSE agar showed a very low selectivity for leuconostoc in our case, with only $16.42 \%$ of the total isolates carried out in this medium representing the microorganims of this genus. The leuconostoc species isolated in Armada cheese agree with those identified in other goat cheeses (Fatichenti et al, 1979; Fontecha et al, 1990; LitopoulouTzanetaki and Tzanetakis, 1992; Mas and González-Crespo, 1992). Leuconostoc mesenteroides subsp dextranicum was the most isolated leuconostoc species, with its presence in 1-week-old cheese ( $25 \%$ of isolates), and 8 -week-old cheese $(17.5 \%$ of isolates) being particularly significant.

The low selectivity shown by MSE agar made the isolated species in this medium throughout ripening a reflection of the overall evolution of lactic acid flora throughout ripening. Lactococci isolates (Lactococcus lactis subsp lactis and Lactococcus lactis subsp cremoris) predominated in milk, curd and 1-week-old cheese, with the lactobacilli (Lactobacillus casei subsp casei, Lactobacillus plantarum and, to a lesser extent, Lactobacillus brevis) being the most frequent species isolated in this medium at the last sampling points. The isolation of Enterococcus malodoratus in almost all sampling points, and in some of them (milk, 2-week-old and 4-week-old cheese) in high 
Table IV. Changes in species isolated from M17 agar during the manufacturing and ripening of Armada cheese (4 batches).

Distribution des espèces isolées dans le milieu M17 durant la fabrication et l'affinage du fromage Armada (4 fabrications).

\begin{tabular}{|c|c|c|c|c|c|c|c|c|c|c|c|c|c|c|}
\hline Species & \multicolumn{2}{|c|}{ Milk } & \multicolumn{2}{|c|}{ Curd } & 1 & & 2 & & 4 & & 8 & & 16 & \\
\hline $\begin{array}{l}\text { Lactococcus lactis subsp lactis } \\
\text { biovar diacetylactis }\end{array}$ & - & - & 2 & 5 & - & - & - & - & - & - & - & - & - & - \\
\hline $\begin{array}{l}\text { Lactococcus lactis } \\
\text { subsp cremoris }\end{array}$ & 1 & 2.5 & 1 & 2.5 & - & - & 4 & 10 & - & - & - & - & - & - \\
\hline Lactobacillus brevis & - & - & - & - & - & - & 1 & 2.5 & - & - & 1 & 2.5 & 4 & 10 \\
\hline Lactobacillus fermentum & - & - & - & - & - & - & 1 & 2.5 & - & - & - & - & 1 & 2.5 \\
\hline Unidentified lactobacilli & - & - & - & - & - & - & - & - & 1 & 2.5 & 1 & 2.5 & 1 & 2.5 \\
\hline
\end{tabular}


Leuconostoc mesenteroides subsp mesenteroides

Leuconostoc mesenteroides subsp dextranicum

Enterococcus malodoratus

\section{Enterococcus faecalis}

\section{Enterococcus faecium}

\section{Enterococcus}

inter faecalis-faecium

Unidentified enterococci

Non lactic acid bacteria

Isolates lost

Total

$10 \quad 25$

$9 \quad 22.5$

$40 \quad 100$

$40 \quad 100$

$40 \quad 100$

40

100

$40 \quad 100$

$40 \quad 100$

$40 \quad 100$ 
Table V. Changes in species isolated from MSE agar during the manufacturing and ripening of Armada cheese (4 batches). Distribution des espèces isolées dans le milieu MSE durant la fabrication et l'affinage du fromage Armada (4 fabrications).

\begin{tabular}{|c|c|c|c|c|c|c|c|c|c|c|c|c|c|c|}
\hline \multirow[t]{3}{*}{ Species } & \multicolumn{2}{|l|}{ Milk } & \multicolumn{2}{|c|}{ Curd } & \multicolumn{10}{|c|}{ Ripening time (weeks) } \\
\hline & & & & & 1 & & 2 & & 4 & & 8 & 8 & 16 & \\
\hline & $\begin{array}{c}\text { No of } \\
\text { isolates }\end{array}$ & (\%) & $\begin{array}{c}\text { No of } \\
\text { isolates }\end{array}$ & (\%) & $\begin{array}{c}\text { No of } \\
\text { isolates }\end{array}$ & $(\%)$ & $\begin{array}{c}\text { No of } \\
\text { isolates }\end{array}$ & (\%) & $\begin{array}{c}\text { No of } \\
\text { isolates }\end{array}$ & (\%) & $\begin{array}{l}\text { No of } \\
\text { isolates }\end{array}$ & (\%) & $\begin{array}{l}\text { No of } \\
\text { isolates }\end{array}$ & s (\%) \\
\hline Lactococcus lactis subsp lactis & 10 & 25 & 13 & 32.5 & 13 & 32.5 & 2 & 5 & - & - & - & - & - & - \\
\hline $\begin{array}{l}\text { Lactococcus lactis } \\
\text { subsp cremoris }\end{array}$ & 6 & 15 & 5 & 12.5 & 3 & 7.5 & 3 & 7.5 & 4 & 10 & - & - & - & - \\
\hline Unidentified lactococci & 2 & 5 & - & - & - & - & - & - & - & - & - & - & - & - \\
\hline Lactobacillus plantarum & 1 & 2.5 & 3 & 7.5 & 2 & 5 & 12 & 30 & 17 & 42.5 & 28 & 70 & 21 & 52.5 \\
\hline Lactobacillus casei subsp casei & - & - & - & - & - & - & 3 & 7.5 & 3 & 7.5 & 2 & 5 & 10 & 25 \\
\hline Lactobacillus brevis & - & - & - & - & - & - & - & - & 1 & 2.5 & 1 & 2.5 & 7 & 17.5 \\
\hline $\begin{array}{l}\text { Leuconostoc mesenteroides } \\
\text { subsp mesenteroides }\end{array}$ & 2 & 5 & 1 & 2.5 & 3 & 7.5 & 4 & 10 & 2 & 5 & - & - & - & - \\
\hline $\begin{array}{l}\text { Leuconostoc mesenteroides } \\
\text { subsp dextranicum }\end{array}$ & 1 & 2.5 & 3 & 7.5 & 10 & 25 & 4 & 10 & 4 & 10 & 7 & 17.5 & - & - \\
\hline
\end{tabular}




\begin{tabular}{|c|c|c|c|c|c|c|c|c|c|c|c|c|c|c|}
\hline Leuconostoc paramesenteroides & - & - & 3 & 7.5 & 2 & 5 & - & - & - & - & - & - & - & - \\
\hline Enterococcus malodoratus & 6 & 15 & - & - & 2 & 5 & 4 & 10 & 7 & 17.5 & 1 & 2.5 & - & - \\
\hline Enterococcus faecalis & 1 & 2.5 & 3 & 7.5 & - & - & - & - & - & - & - & - & - & - \\
\hline \multicolumn{15}{|l|}{ Enterococcus } \\
\hline inter faecalis-faecium & - & - & 1 & 2.5 & - & - & - & - & - & - & - & - & - & - \\
\hline Unidentified enterococci & 1 & 2.5 & - & - & - & - & - & - & - & - & - & - & - & - \\
\hline Non lactic acid bacteria & - & - & - & - & - & - & 1 & 2.5 & - & - & 1 & 2.5 & 1 & 2.5 \\
\hline Isolates lost & 10 & 25 & 8 & 20 & 5 & 12.5 & 7 & 17.5 & 2 & 5 & - & - & 1 & 2.5 \\
\hline Total & 40 & 100 & 40 & 100 & 40 & 100 & 40 & 100 & 40 & 100 & 40 & 100 & 40 & 100 \\
\hline
\end{tabular}


Table VI. Changes in species isolated from Rogosa agar during the manufacturing and ripening of Armada cheese (4 batches). Distribution des espèces isolées dans le milieu de Rogosa durant la fabrication et l'affinage du fromage Armada (4 fabrications).

\begin{tabular}{|c|c|c|c|c|c|c|c|c|c|c|c|c|c|c|}
\hline \multirow[t]{3}{*}{ Species } & \multirow{2}{*}{\multicolumn{2}{|c|}{ Milk }} & \multirow{2}{*}{\multicolumn{2}{|c|}{ Curd }} & \multicolumn{10}{|c|}{ Ripening time (weeks) } \\
\hline & & & & & \multicolumn{2}{|l|}{1} & \multicolumn{2}{|l|}{2} & \multicolumn{2}{|l|}{4} & \multicolumn{2}{|l|}{8} & \multicolumn{2}{|l|}{16} \\
\hline & $\begin{array}{l}\text { No of } \\
\text { isolates }\end{array}$ & $(\%)$ & $\begin{array}{l}\text { No of } \\
\text { isolates }\end{array}$ & $(\%)$ & $\begin{array}{l}\text { No of } \\
\text { isolates }\end{array}$ & (\%) & $\begin{array}{l}\text { No of } \\
\text { isolates }\end{array}$ & $(\%)$ & $\begin{array}{l}\text { No of } \\
\text { isolates }\end{array}$ & (\%) & $\begin{array}{l}\text { No of } \\
\text { isolates }\end{array}$ & (\%) & $\begin{array}{c}\text { No of } \\
\text { isolates }\end{array}$ & (\%) \\
\hline Lactococcus lactis subsp lactis & - & - & 1 & 2.5 & - & - & - & - & - & - & - & - & - & - \\
\hline Lactobacillus plantarum & 8 & 20 & 9 & 22.5 & 19 & 47.5 & 21 & 52.5 & 19 & 47.5 & 23 & 57.5 & 6 & 15 \\
\hline Lactobacillus casei subsp casei & 26 & 65 & 20 & 50 & 16 & 40 & 12 & 30 & 17 & 42.5 & 13 & 32.5 & 16 & 40 \\
\hline $\begin{array}{l}\text { Lactobacillus casei } \\
\text { subsp alactosus }\end{array}$ & 1 & 2.5 & - & - & 1 & 2.5 & - & - & - & - & 1 & 2.5 & 1 & 2.5 \\
\hline Lactobacillus brevis & 1 & 2.5 & - & - & - & - & 1 & 2.5 & - & - & - & - & 8 & 20 \\
\hline Unidentified lactobacilli & - & - & - & - & - & - & - & - & 1 & 2.5 & 1 & 2.5 & - & - \\
\hline $\begin{array}{l}\text { Leuconostoc mesenteroides } \\
\text { subsp dextranicum }\end{array}$ & - & - & 4 & 10 & - & - & - & - & - & - & - & - & - & - \\
\hline Unidentified enterococci & 1 & 2.5 & 1 & 2.5 & - & - & - & - & - & - & - & - & - & - \\
\hline Non lactic acid bacteria & 1 & 2.5 & - & - & - & - & 1 & 2.5 & - & - & - & - & - & - \\
\hline Isolates lost & 2 & 5 & 5 & 12.5 & 4 & 10 & 5 & 12.5 & 3 & 7.5 & 2 & 5 & 9 & 22.5 \\
\hline Total & 40 & 100 & 40 & 100 & 40 & 100 & 40 & 100 & 40 & 100 & 40 & 100 & 40 & 100 \\
\hline
\end{tabular}


proportions, was also noticeable. The fact that this species, also described in Gouda cheese (Collins et al, 1984), does not figure among the enterococci species isolated in KAA agar is unusual.

The number of isolates lost in this medium was also important, particularly at the first sampling points. As occurred in $\mathrm{M} 17$ agar, almost all the losses were produced when the strains were grown in MRS medium. This makes us suspect that these strains were yeasts and other non-lactic acid flora.

Table VI shows the evolution of the species isolated from Rogosa agar during ripening. Rogosa agar showed a high selectivity for lactobacilli, which made up $86.42 \%$ of all isolations carried out in this medium. The main species isolated were Lactobacillus casei subsp casei and Lactobacillus plantarum in practically the same proportion and with a fairly equal distribution at all sampling points. These 2 species were also mainly isolated in other goat cheeses such as artisanal Majorero (Fontecha et al, 1990), industrial Majorero (Gómez et al, 1989), white-brined cheese (Litopoulou-Tzanetaki and Tzanetakis, 1992) and lbores (Mas and González-Crespo, 1992). However, the predominance of Lactobacillus plantarum was very evident in almost all of these cases.

The only heterofermentative lactobacilli species isolated was Lactobacillus brevis only reaching important proportions in 16 week-old cheese ( $20 \%$ of isolates); its presence in milk ( $2.5 \%$ of isolates) and 2 -weekold cheese ( $2.5 \%$ of isolates) was minimal. The isolation on Rogosa agar of other nonlactobacilli lactic acid bacteria was minimal (only 1 isolate was identified as Lactococcus lactis subsp lactis, 4 identified as Leuconostoc mesenteroides subsp dextranicum and 2 isolates of unidentified enterococci).

Table VII shows the evolution of the isolated species from KAA agar throughout ripening. From the identity of isolates, we can conclude that this medium showed an almost absolute selectivity for enterococci. Only at the last sampling point were 6 nonenterococci strains isolated ( 1 identified as Lactobacillus casei subsp casei and 5 identified as Lactobacillus casei subsp alactosus).

Enterococcus faecalis was the predominant species, constituting $100 \%$ of the isolates carried out in 2-week-old cheese and a percentage higher than $60 \%$ at all the other sampling points. A considerable number of isolates (10) showed characteristics very close to Enterococcus faecalis without strictly fullfilling the biochemical and cultural standards of this species; for this reason we feel more correct in including them under the name of Enterococcus like-faecalis. Six isolates were identified as Enterococcus durans and only 1 as Enterococcus faecium. Finally, 18 isolates showed intermediate characteristics between Enterococcus faecalis and Enterococcus faecium and they were considered as Enterococcus inter faecalis-faecium.

Enterococcus faecalis has also been described as the most dominant enterococci species in other artisanal goat cheeses such as Sardinia (Fatichenti et al, 1979), Majorero (Fontecha et al, 1990) and lbores (Mas and González-Crespo, 1992). Only in whitebrined raw goat's milk cheese (LitopoulouTzanetaki and Tzanetakis, 1992) did Enterococcus faecium dominate over the other species of enterococci.

In the 4 culture media, no appreciable differences in the isolated species were observed related to the ripening season.

\section{ACKNOWLEDGMENTS}

This study was financially supported by the Junta de Castilla y León (the regional government). ME Tornadijo was awarded a grant from the Consejería de Agricultura y Ganaderia of the Junta de Castilla y León. 
Table VII. Changes in species isolated from KAA agar during the manufacturing and ripening of Armada cheese (4 batches). Distribution des espèces isolées dans le milieu KAA durant la fabrication et l'affinage du fromage Armada (4 fabrications).

\begin{tabular}{|c|c|c|c|c|c|c|c|c|c|c|c|c|c|c|}
\hline \multirow[t]{3}{*}{ Species } & \multicolumn{2}{|c|}{ Milk } & \multirow{2}{*}{\multicolumn{2}{|c|}{ Curd }} & \multicolumn{10}{|c|}{ Ripening time (weeks) } \\
\hline & \multirow[b]{2}{*}{$\begin{array}{l}\text { No of } \\
\text { isolates }\end{array}$} & \multirow[b]{2}{*}{$(\%)$} & & & \multicolumn{2}{|l|}{1} & \multicolumn{2}{|c|}{2} & \multicolumn{2}{|c|}{4} & \multicolumn{2}{|c|}{8} & \multicolumn{2}{|c|}{16} \\
\hline & & & $\begin{array}{l}\text { No of } \\
\text { isolates }\end{array}$ & $(\%)$ & $\begin{array}{l}\text { No of } \\
\text { isolates }\end{array}$ & (\%) & $\begin{array}{l}\text { No of } \\
\text { isolates }\end{array}$ & $(\%)$ & $\begin{array}{l}\text { No of } \\
\text { isolates }\end{array}$ & $(\%)$ & $\begin{array}{l}\text { No of } \\
\text { isolates }\end{array}$ & $(\%)$ & $\begin{array}{l}\text { No of } \\
\text { isolates }\end{array}$ & $s(\%)$ \\
\hline Enterococcus faecalis & 28 & 70 & 28 & 70 & 29 & 72.5 & 40 & 100 & 37 & 92.5 & 30 & 75 & 19 & 63.3 \\
\hline Enterococcus like-faecalis & 1 & 2.5 & 3 & 7.5 & 4 & 10 & - & - & - & - & 1 & 2.5 & 1 & 3.3 \\
\hline Enterococcus faecium & - & - & - & - & - & - & - & - & - & - & 1 & 2.5 & - & - \\
\hline Enterococcus durans & - & - & 2 & 5 & - & - & - & - & 1 & 2.5 & 3 & 7.5 & - & - \\
\hline $\begin{array}{l}\text { Enterococcus } \\
\text { inter faecalis-faecium }\end{array}$ & 10 & 25 & 1 & 2.5 & 4 & 10 & - & - & 1 & 2.5 & 2 & 5 & - & - \\
\hline Unidentified enterococci & - & - & - & - & 1 & 2.5 & - & - & 1 & 2.5 & - & - & - & - \\
\hline Lactobacillus casei subsp casei & - & - & - & - & - & - & - & - & - & - & - & - & 1 & 3.3 \\
\hline $\begin{array}{l}\text { Lactobacillus casei } \\
\text { subsp alactosus }\end{array}$ & - & - & - & - & - & - & - & - & - & - & - & - & 5 & 16.6 \\
\hline Isolates lost & 1 & 2.5 & 6 & 15 & 2 & 5 & - & - & - & - & 3 & 7.5 & 4 & 13.3 \\
\hline Total & 40 & 100 & 40 & 100 & 40 & 100 & 40 & 100 & 40 & 100 & 40 & 100 & 40 & 100 \\
\hline
\end{tabular}




\section{REFERENCES}

AOAC (1975) Hydrogen-ion activity $(\rho \mathrm{H})$. Potentiometric method. Official methods of analysis. 12th edn. Washington DC, USA. Method 14022

Chapman GH (1945) The significance of sodium chloride on studies of Staphylococci. J Bacterio/ 50, 201-203

Collins MD, Jones D, Farrow JAE, Kilpper-Bälz R, Schleifer KH (1984) Enterococcus avium nom rev, comb nov; $E$ casseliflavus nom rev, comb nov; $\mathrm{E}$ durans nom rev, comb nov; $E$ gallinarum comb nov and $E$ malodoratus sp nov. Int J Syst Bacteriol 34. 220-223

Colman G, Ball LC (1984) Identification of streptococci in a medical laboratory. J App/ Bacterio/ $57,1-14$

De Giori GS, De Valdez GF, De Ruiz Holgado AP, Oliver G (1983) Microflora of Tafi cheese: changes during manufacture and maturation. J Food Prot 46, 518521

Devriese LA, van de Kerckhove A, Kilpper-Bälz R, Schleifer KH (1987) Characterization and identification of Enterococcus species isolated from the intestines of animals. Int $J$ Syst Bacteriol 37, 257 259

Espie WE, Mullan WMA (1987) Microbiological aspects of the quality of goat milk in Northern Ireland. Milchwissenschaft 42, 762-764

Fatichenti F, Deiana P, Farris GA, Soggia G (1979) Etudes microbiologiques sur le lait et le fromage de chèvre en Sardaigne. Note II : streptocoques, lactobacilles et leuconostoc. Lait 59, 387-400

Fernández del Pozo B, Gaya P, Medina M, Rodríguez Marín MA, Núnez M (1988) Changes in the microflora of La Serena ewes' milk cheese during ripening. J Dairy Res 55, 449-455

Fontecha J, Peláez C, Juárez M. Requena T, Gómez C, Ramos M (1990) Biochemical and microbiological characteristics of artisanal hard goat's cheese. J Dairy Sci $73,1150-1157$

Garvie El (1984) Separation of species of the genus Leuconostoc and differentiation of the Leuconostoc from other lactic acid bacteria. Methods Microbiol $16,147-178$

Garvie El (1986) Genus Leuconostoc. In: Bergey's manual of systematic bacteriology, Vol 2 (PHA Sneath, NS Mair, ME Sharpe, JG Holt, eds) The Williams and Wilkins Company, Baltimore, MD, USA

Gómez R, Peláez C, de la Torre E (1989) Microbiological study of semi-hard goat's milk cheese (Majorero). Int J Food Sci Technol 24, 147-151

Gutièrrez LM. Carballo J, Vidal I, González Prieto J, Martin Sarmiento R, Bernardo A (1988) Evolución de los principales grupos de microorganismos durante la elaboración y maduración del queso de Valde. teja. An Fac Vet León 34, 119-126
Harrigan WF, McCance ME (1976a) Statistical methods for the selection and examination of microbial colonies. In: Laboratory methods in foods and dairy microbiology (WF Harrigan, ME McCance, eds) Academic Press, London, UK

Harrigan WF, McCance ME (1976b). Recipes for stains, reagents and media. In: Laboratory methods in foods and dairy microbiology (WF Harrigan, McCance ME, eds) Academic Press, London, UK

ICMSF (1978) Microorganisms in foods. I. Their significance and methods of enumeration. 2nd edn. University of Toronto Press, Toronto, Canada

IDF (1972) Determination of the salt content of cheese. IDF Standard 17A

IDF (1982) Cheese and processed cheese. Determination of the total solids content. IDF Standard $4 \mathrm{~A}$

IDF (1987) Milk, cream and evaporated milk - Total solids. IDF Standard 21B

Kandler O, Weiss N (1986) Genus Lactobacillus. In: Bergey's manual of systematic bacteriology, Vol 2 (PHA Sneath, NS Mair, ME Sharpe, JG Holt, eds) The Williams and Wilkins Company, Baltimore, MD. USA

Litopoulou-Tzanetaki E, Tzanetakis N (1992) Microbiological study of white-brined cheese made from raw goat milk. Food Microbiol 9, 13-19

MAPA (1990) Catálogo de quesos de España. 2nd edn. Ministerio de Agricultura, Pesca y Alimentación, Madrid, Spain

Mas M, González-Crespo J (1992) Bacterias lácticas en el queso de los Ibores. Alimentaria 230, 41-43

Mas Mayoral M, Timón Esteban J, González-Crespo J (1991) Queso de los Ibores: caracterización productiva, físico-química y microbiológica. Arch Zootech $40,103-113$

Mayeux JV, Sandine WE, Elliker PR (1962) A selective medium for detecting Leuconostoc organisms in mixed-strain starter cultures. J Dairy Sci 45, 655-656

McDonald LC. Fleming HP, Hassan HM (1990) Acid tolerance of Leuconostoc mesenteroides and Lactobacillus plantarum. Appl Environ Microbiol 56, 21202124

Medina M, Gaya P, Nủnez M (1992) Gredos goats' milk cheese: microbiological and chemical changes throughout ripening. J Dairy Res 59, 563-566

Mor-Mur M, Carretero C, Pla R, Guamis B (1992) A survey on the microbiological quality of a semi-soft onfarm manufactured goat cheese. Food Microbiol 9 , 345-352

Mossel DAA, Kleynen-Semmeling AMC, Vincentie HM. Beerens H, Catsaras M (1970) Oxytetracycline-glucose-yeasts extract agar for selective enumeration of moulds and yeasts in foods and clinical material. J Appl Bacterio/ 33, 454-457

Mossel DAA, Bijker PGH. Eelderink I (1978) Streptokokken der Lancefield-Gruppe D in Lebensmitteln 
und Trinkwasser-Ihre Bedeutung, Erfassung und Bekämpfung. Arch Lebensmittelhyg 29, 121-127

Mundt JO (1986a) Lactic acid streptococci. In: Bergey's manual of systematic bacteriology, Vol 2 ( $\mathrm{PHA}$ Sneath, NS Mair, ME Sharpe, JG Holt, eds) The Williams and Wilkins Company, Baltimore, MD, USA

Mundt JO (1986b) Enterococci. In: Bergey's manual of systematic bacteriology, Vol 2 (PHA Sneath, NS Mair, ME Sharpe, JG Holt, eds) The Williams and Wilkins Company, Baltimore, MD, USA

Norme Française Homologuée (1969) Lait : détermination de la teneur en chlorures. NF V 04-212

Núñez M (1976) Flora microbiana del queso Manchego. IV. Lactobacilos. An INIA Ser General 4, 57-65

Núñez M (1978) Microflora of Cabrales cheese: changes during maturation. J Dairy Res 45, 501-508

Poullet B, Huertas M, Sánchez A, Cáceres P, Larriba G (1991) Microbial study of Casar de Cáceres cheese throughout ripening. J Dairy Res 58, 231-238

Rogosa M, Mitchell JA, Wiseman RF (1951) A selective medium for the isolation and enumeration of oral and fecal lactobacilli. J Bacteriol 62, 132-133
Sharpe ME (1979) Identification of lactic acid bacteria. In: Identification methods for microbiologists (FA Skinner, DW Lovelock, eds) Academic Press, London, UK

Tatini SR, Jezeski JJ, Morris HA, Olson JC, Casman EP (1971) Production of staphylococcal enterotoxin A in Cheddar and Colby cheeses. J Dairy Sci 54, 815-825

Terzaghi BE, Sandine WE (1975) Improved medium for lactic streptococci and their bacteriophages. Appl Microbiol 29, 807-813

Tirard-Collet P, Zee JA, Carmichael L, Simard RE (1991) A study of the microbiological quality of goat milk in Quebec. J Food Prot 54, 263-266

Tornadijo E, Fresno JM, Carballo J, Martín Sarmiento R (1993) Study of Enterobacteriaceae throughout the manufacturing and ripening of hard goats' cheese. J App/ Bacteriol 75, 240-246

Tzanetakis N, Litopoulou-Tzanetaki E (1992) Changes in numbers and kinds of lactic acid bacteria in Feta and Teleme, two Greek cheeses from ewes' milk. J Dairy Sci 75, 1389-1393 